\title{
A Comparative Experimental Study of Gas Injection in Shale Plugs by Flooding and Huff-N-Puff Processes
}

\author{
Yang Yu, Lei Li, and James J. Sheng* \\ Bob L. Herd Department of Petroleum Engineering, Texas Tech University, Lubbock, TX 79409, United States \\ *Corresponding author: \\ Tel: +1 806.834.8477, Email: james.sheng@ttu.edu
}

\begin{abstract}
The increase in U.S crude oil over the past decade have been primarily driven by tight and shale oil. With the high production decline rates in shale reservoirs, improved oil recovery techniques must be applied to maintain the oil recovery from existing wells. Gas injection has been investigated and demonstrated as the most effective solution to face such challenge. As gas can be injected into the subsurface by two modes: continuous injection (flooding) and cyclic injection (huff-n-puff), this study aims to compare the recovery efficiencies of such two processes in shale core plugs with ultra-low matrix permeability.

Eagle Ford core samples were used in this study and saturated with shale oil. Using $\mathrm{N}_{2}$ as the gas source, gas injection tests were operated on the same plug orderly by both modes under the same operating conditions. The sensitivity of soaking time on the huff-n-puff performance was evaluated. Lab-scale numerical models were built to simulate flooding and huff-n-puff processes and to history match the experimental data. It was found that optimization design of huff-n-puff is important to achieve the maximum oil recovery. The results show that the huff-n-puff possess can achieve a higher oil recovery than the flooding process.
\end{abstract}

Key Words: Gas Flooding, Gas Huff-N-Puff, Improved Oil Recovery, Shale Reservoirs, Shale Oil

\section{Introduction}

In the following decades, U.S tight and shale oil production will remain stable and keep growing gradually. As Figure 1 shows, although the tight oil production fell to 4.1 million b/d in June 2016 (EIA, 2016a), the U.S. tight oil is expected to increase from 4.2 million b/d in 2017 to 7.1 million b/d in 2040 in the AEO2016 Reference case (EIA, 2016b). The horizontal wells drilled in shale formations usually begin producing at very high rates, then they fall off very sharply, and finally they level off at a much lower rate (Ma, 2015; Yuan, 2015). The improving fracturing technology contributes to the shale oil recovery. Yuan et al. (2016) proposed an integrated approach to evaluate the efficiency of fracturing stimulation and predict well production performance, by which the ultimate recovery, optimal fracture spacing, and the horizontal section length can be obtained. However, the sustainable development of shale reservoirs and improving the oil recovery is becoming a new challenge. Operators also show rising interest in maximizing shale oil production. In order to extend the productive life of existing wells, improved oil recovery (IOR) techniques must be applied to tight and shale reservoirs after the primary depletion as well as during the high declines rates period. Through analyzing the test results from IOR pilot projects by injecting gas or water in the Bakken formation, Hoffman and Evans (2016) proposed the feasibility of injection fluids into very low 
permeability reservoirs, but the major issue is conformance control that the projects show early breakthrough times and poor sweep efficiencies. In order to achieve more than $20 \%$ of recovery factors in unconventional reservoirs, they emphasized the necessity of IOR techniques and the significance of developing effective injection fluid and injection methods.

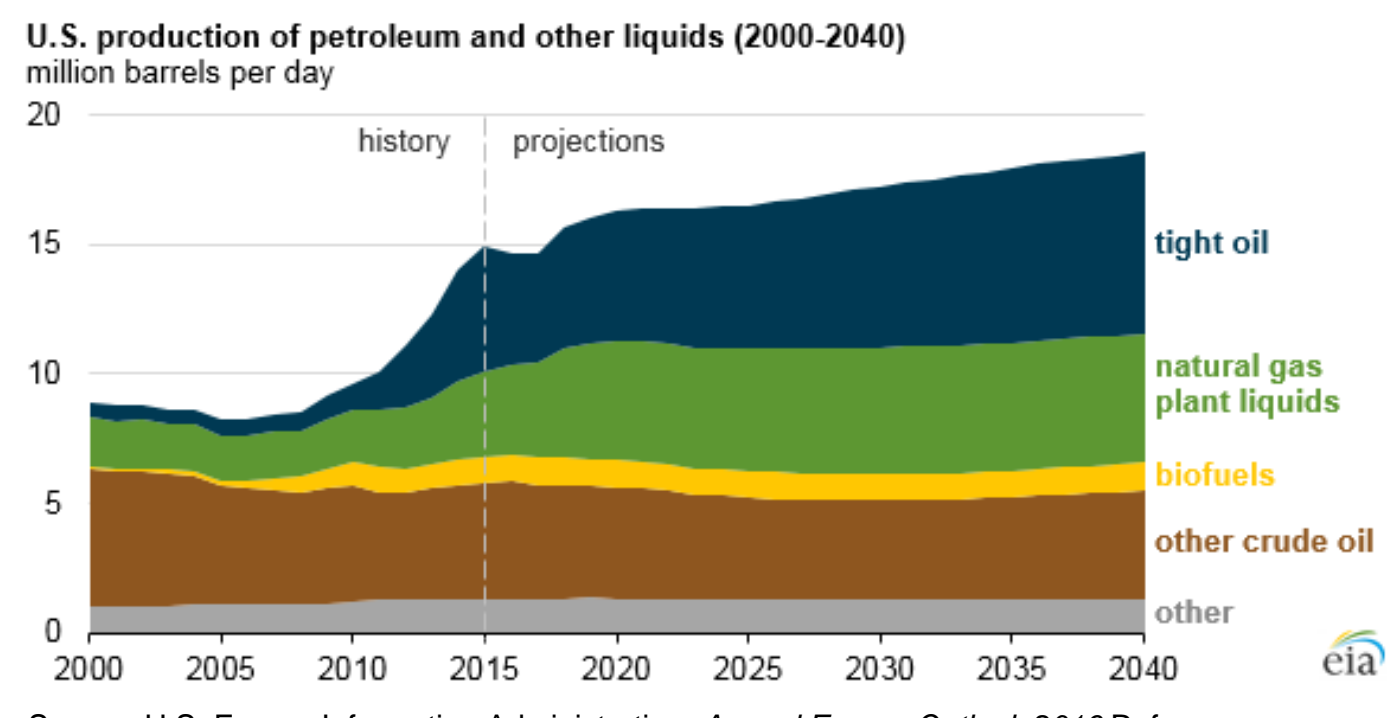

Source: U.S. Energy Information Administration, Annual Energy Outlook 2016 Reference case

Figure 1. Projection of U.S. petroleum and other liquid fuels production

Gas injection is a developed and successful IOR technique for recovering oil from conventional reservoirs. It has been demonstrated as most effective and promising IOR method in shale reservoirs by many recent publications (Dong and Hoffman, 2013; Yu et al., 2014; Sheng, 2014; Zhu et al., 2015; Kong et al., 2016). Generally, gas can be injected into the reservoir in two modes: continuous flooding and huff-n-puff injection, while both have their own advantages and limitations. For the well-to-well flooding process, the gas is continuously injected to the reservoir formation to displace the residual oil to adjacent production wells. The huff-n-puff injection process is related to a single-well that the gas is cyclically injected into the reservoir. Each cycle involves three phases: reservoir pressure build-up (huff), pressure equilibration and fluids interaction (soaking), and pressure depletion for production (puff).

There have been some reservoir simulation studies that evaluated and compared the recovery performances between such two processes in shale plays (Song and Yang, 2013; Wan et al., 2014; Wan and Sheng, 2015a). Experimentally, our research team have evaluated the IOR potential of gas huff-n-puff process and gas flooding process using shale plugs separately. Gamadi et al. (2013) investigated the recovery performance of cyclic $\mathrm{N}_{2}$ injection process in fractured shale reservoirs. Various types of shale outcrop plugs were used (Barnett, Marcos, and Eagle Ford) and saturated with mineral oil (Soltrol 130). They examined the effects of soaking time and injection pressure on the recovery efficiency. Results demonstrated the recovery potential of $\mathrm{N}_{2}$ cyclic injection process in shale oil reservoirs, with RFs from $10 \%$ to $50 \%$ depending upon the operating conditions and core type. They also investigated the recovery performance of $\mathrm{CO}_{2}$ cyclic injection in the following study (Gamadi et al., 2014). Miscible $\mathrm{CO}_{2}$ injection had a positive influence on RF compared to immiscible injection. The effect of soaking period in the cyclic injection process was highlighted because the shale plugs have ultra-low matrix 
permeability, so a longer soaking time gives a higher ultimate RF. Yu et al. (2016) further discussed the roles of soaking time and pressure depletion rate in gas huff-n-puff process in fractured shale reservoirs. Applying methane as the gas source, Li et al. (2015) conducted the upscale study on evaluating the gas huff-n-puff recovery efficiency in shale plays. As the operation of huff-n-puff process involves many sensitive parameters which can greatly affect the recovery performance, Li et al. (2016) also performed the optimization design of gas huff-n-puff in shale reservoirs to enhance oil recovery. For the gas flooding study, Yu et al. (2016b) investigated the effects of injection pressure and recovery period on the shale oil recovery. More literature information can be found in Sheng, 2015. From the simulation results and laboratory observations, the huff-n-puff process presented outstanding recovery performance. However, limited experimental work has been conducted to compare the efficiencies of two displacement processes under the same operating conditions.

This study aims to compare the recovery performances of gas flooding and gas huff-n-puff in shale core plugs. The two injection modes were performed under the same injection pressure and operation period to recover oil from Eagle Ford core samples with matrix permeability in the nano-Darcy range. In addition, lab-scale simulation models were built to history match the experimental data and to explore the recovery characteristics of such two injection processes.

\section{Experimental Work}

\subsection{Materials}

Two shale core plugs were used in this study. They were cut from different locations of the Eagle Ford outcrop, thus presented different properties of porosity and permeability. Table 1 gives the plug dimensions and properties. Oil sample was dead oil from Wolfcamp shale play with the density of $0.815 \mathrm{~g} / \mathrm{cm}^{3}$ and viscosity of $8.5 \mathrm{cp}$, which were measured at the temperature of $72{ }^{\circ} \mathrm{F}$ and atmospheric pressure. Nitrogen gas with the purity of $99.999 \%$ was used as the displacement medium in gas injection tests.

Table 1. Core plug properties

\begin{tabular}{cccccc}
\hline Core No. & $\begin{array}{c}\text { Diameter } \\
(\mathrm{mm})\end{array}$ & $\begin{array}{c}\text { Length } \\
(\mathrm{mm})\end{array}$ & $\begin{array}{c}\text { Dry weight } \\
(\mathrm{g})\end{array}$ & $\begin{array}{c}\text { Saturation } \\
\text { Porosity }\end{array}$ & $\begin{array}{c}\text { Average Permeability } \\
(\mathrm{nD})\end{array}$ \\
\hline CEF_1 & 38.5 & 50.9 & 152.099 & $4.4 \%$ & 85 \\
CEF_2 & 38.1 & 101.8 & 249.697 & $13.1 \%$ & 400 \\
\hline
\end{tabular}

\subsection{Experimental Setup and Design}

Core samples were saturated with oil followed by performing gas injection tests. For the saturation process, the core plug was placed in an oven for drying 1 day and weighted $\left(W_{\text {dry }}\right)$. Subsequently, it was placed in a vessel and vacuumed for 1 day. After that, using a displacement pump (QX-6000), the oil was delivered into the vessel under a constant pressure of 1,000 psi for 1 day for maximum saturation. Then, the core was removed from oil and weighted $\left(W_{\text {sat }}\right)$ after a few hours to stabilize the weight and equilibrate the matrix pressure. The detailed setup, operation procedures of core saturation, and data uncertainty analysis for individual test can be referred to our previous paper (Yu et al., 2016) and Yu's dissertation (Yu, 2016). 
The experimental setup for $\mathrm{N}_{2}$ flooding and $\mathrm{N}_{2}$ huff-n-puff are shown in Figure 2. To minimize experimental errors and diminish the effect of sample difference on results, same plug was used to perform both modes of gas injection recovery processes. Table 2 presents the operating parameters. Two core samples, CEF_1 and CEF_2, were used to operate the gas injection tests for a total operation period of 2-day and 3-day, respectively. For all tests, the injection pressure was $1,000 \mathrm{psi}$, and the confining pressure was $500 \mathrm{psi}$ higher than the injection pressure. The production pressure was set as atmospheric pressure. As the temperature effect on recovery factor (RF) was not the focus in this study and for the convenience of operation, all tests were operated at the room temperature of $72^{\circ} \mathrm{F}$. When performing the tests on the same plug, the $\mathrm{N}_{2}$ flooding process was operated initially followed by the $\mathrm{N}_{2}$ huff-n-puff process. The RF of each test was determined by the weight loss of the core sample (the ratio of produced oil to saturated oil in the plug).

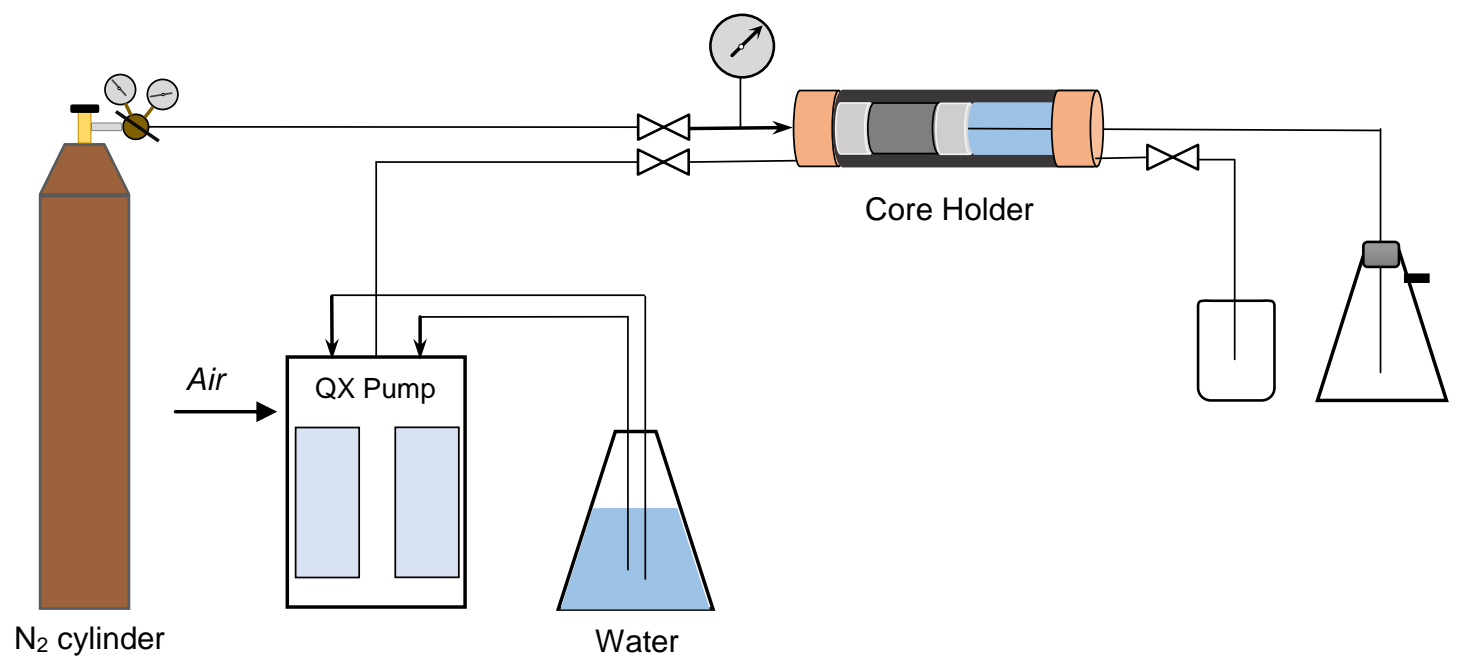

(a)

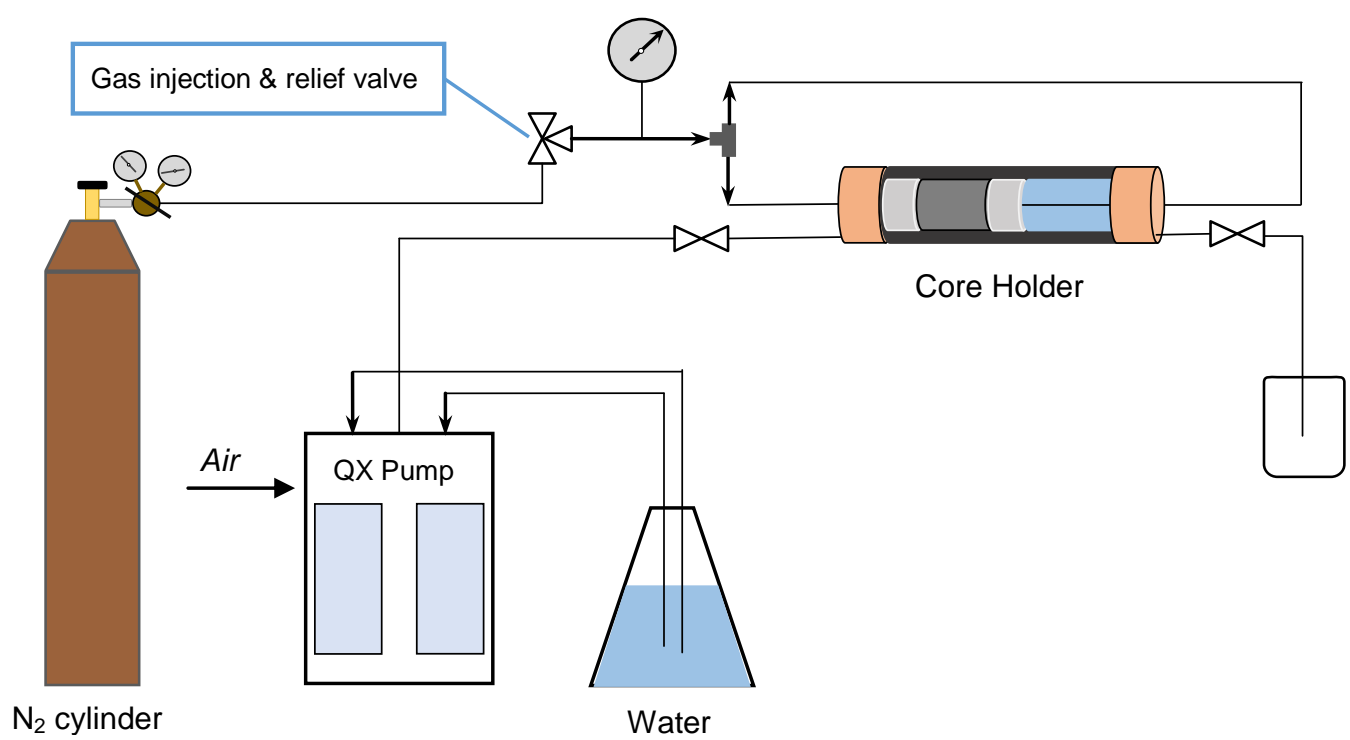

(b)

Figure 2. Diagram of experimental setup for (a) gas flooding and (b) gas huff-n-puff tests 
Table 2. Operating parameters for gas injection tests

\begin{tabular}{cccl}
\hline Core No. & Gas Injection Mode & Test No. & \multicolumn{1}{c}{ Operating Parameters } \\
\hline FEF_1 & Flooding & 1 & Flooding period: 2 days \\
& Huff-N-Puff & 2 & $\begin{array}{l}\text { Soaking } 0.5 \mathrm{hrs}, \text { production } 1 \mathrm{hr}(32 \mathrm{cycles}) \\
\text { Soaking } 2 \mathrm{hrs}, \text { production } 1 \mathrm{hr}(16 \mathrm{cycles})\end{array}$ \\
\hline CEF_2 & 3 & 4 & Soaking $5 \mathrm{hrs}$, production $1 \mathrm{hr}(8 \mathrm{cycles})$ \\
\hline
\end{tabular}

$\mathrm{N}_{2}$ Flooding Process: Two gas flooding tests were conducted on core CEF_1 and core CEF_2 under the designed operating parameters. After each test, the plugs were re-saturated with oil and used for the huff-n-puff tests.

$\mathrm{N}_{2}$ Huff-N-Puff Process: When operating the huff-n-puff tests, the core plug was placed in the core holder with a sleeve rubber. After applying the confining pressure, $\mathrm{N}_{2}$ was injected into the plug from both sides of the holder (huff stage), so both faces of the plug could contact with the injected gas, as shown in Figure 2 (b). Once the system pressure achieved 1,000 psi, the gas source valve was closed for a certain period (soaking stage). Then the system pressure was released down to the atmospheric pressure to allow oil to come out from the core plug (puff stage). These operations simulated the gas huff-n-puff process for a single well.

For core CEF_1, such process was conducted at three soaking times of 0.5-hr, 2-hr, and 5-hr, respectively, and the production time was $1-\mathrm{hr}$ for all cases. This aims to study the soaking time effect on RF in a non-fracture shale system. For core CEF_2, to achieve the maximum recovery, we selected 1-hr as the soaking time and 3-hr as the production time. Such design allows more cycles of huff-n-puff could be operated within a controlled operation period, and offers enough time for oil production after each cycle.

\section{Simulation Model Description}

A core-scale numerical model was built using a commercial simulator, CMG-GEM, to simulate the $\mathrm{N}_{2}$ flooding and $\mathrm{N}_{2}$ huff-n-puff processes in a shale plug (core CEF_2). The simulation software has a numerical dispersion control option, which blends the usual upstreamed fluxes with higher-order, averaged, two-point fluxes under the control of a Total Variation Limiting (TVD) flux limiter. The TVD limiter ensures that the overall numerical scheme maintains numerical stability and eliminates over- and under-shoot in the calculations. The limiter allows the higher-order flux calculation to predominate away from the edges of saturation fronts and fluid banks, and reverts to the more stable upstream scheme near frontal regions where compositional variable and/or saturations are changing rapidly (CMG, 2014). The domain was discretized into $33 \times 1 \times 10$ Cartesian grid blocks with the dimension of $4 \times 1.5 \times 1.5$ in. The cores were cylindrical. The cores we used in our experiment were horizontally placed in the core holder. Using the experimental methods of gas flooding and gas huff-n-puff, the gas was 
injected from one end and flow out from the other end (flooding), or injected from the two end sides of the core (huff-n-puff), so the fluid flow is liner flow in the experiment. The Cartesian simulation model is the best and most convenient model to describe the linear flow. The factor which affects the oil recovery results is the ratio of the superficial area to volume (SA/V). The (SA/V) from the Cartesian model are the same from the cylindrical cores in this experiments. We used the same model to simulate the gas flooding and gas huff-n-puff, which eliminate the size shape effect for comparison.

Figure 3 shows the 3-D view of the reservoir simulation model. There were two wells built in the model. For the flooding process, along the $\mathrm{X}$ direction, one well was located at the left side as the injector and the other one was located at the right side as the producer. The gas was continuously injected into the reservoir from left side during the whole operation period. For the huff-n-puff process, during the huff phase, the two wells on both sides of the reservoir were designed as injection wells that gas could be introduced into the formation simultaneously. Once the injection pressure achieved, both wells were shut-in to enter the soaking phase. After the designed soaking period, the two wells were re-opened to allow the oil and gas production. Above practices were one cycle of huff-n-puff, which was repeated throughout the operation period.

The model has 33 layers in $\mathrm{X}$ direction to present the fluids motion behavior during the gas injection or pressure depletion period. $\mathrm{Z}$ direction was divided into 10 layers that allowed gas to be injected into, and gas and oil to be produced from each layer, as the performance of the physical gas injection test. The dead oil compositional analysis results are shown in Table 3 . The reservoir properties and recovery conditions of the base model are given in Table 4, with a matrix permeability of 400 nano-Darcy and injection pressure of 1,000 psi. The distribution of porosity, absolute permeability, and oil saturation were assumed to be homogeneous in the shale matrix. In order to history match the experimental measurements, the model input parameters including shale matrix permeability and porosity, relative permeability, and diffusivity of the oil and gas phases were tuned within a reasonable range.

The preliminary input relative permeability data were referred to in previous simulation work ( $\mathrm{Yu}$ et al, 2016), which simulated the $\mathrm{N}_{2}$ flooding process in the same type of shale rocks. Combined with the experimental results from CEF_2, relative permeability typical curve for each mode of gas injection was tuned to match the corresponding oil production history. Thus we generated two base models. The well-tuned models were used to compare the performances of flooding and huff-n-puff processes, interpret experimental results, and predict the oil recovery.

Table 3. Input fluid composition

\begin{tabular}{cccccc}
\hline Component & $\mathrm{C}_{3}-\mathrm{nC}_{4}$ & $\mathrm{iC}_{5}-\mathrm{C}_{8}$ & $\mathrm{C}_{9}-\mathrm{C}_{19}$ & $\mathrm{C}_{20}-\mathrm{C}_{40}$ & $\mathrm{C}_{41}-\mathrm{C}_{42}$ \\
\hline Mole Fraction (\%) & 0.018 & 2.64 & 36.66 & 45.32 & 15.36 \\
\hline
\end{tabular}

Table 4. Reservoir properties and recovery conditions of the base model

\begin{tabular}{|c|c|c|}
\hline Property & Value & Units \\
\hline Shale matrix permeability & 400 & $\mathrm{nD}$ \\
\hline Shale matrix porosity & $9.7 \%$ & fraction \\
\hline Initial oil saturation & $100 \%$ & fraction \\
\hline Initial core pressure & 14 & psi \\
\hline
\end{tabular}




\begin{tabular}{lcc} 
Reservoir temperature & 72 & ${ }^{\circ} \mathrm{F}$ \\
Injection pressure $\mathrm{P}_{\text {in }}$ & 1000 & $\mathrm{psi}$ \\
Production pressure $\mathrm{P}_{\text {out }}$ & 14 & $\mathrm{psi}$ \\
Compressibility of shale & $5 \times 10^{-6}$ & $\mathrm{psi}^{-1}$ \\
Injected gas & $\mathrm{N}_{2}$ & $\mathrm{~N} / \mathrm{A}$ \\
Operation period & 3 & day \\
\hline
\end{tabular}

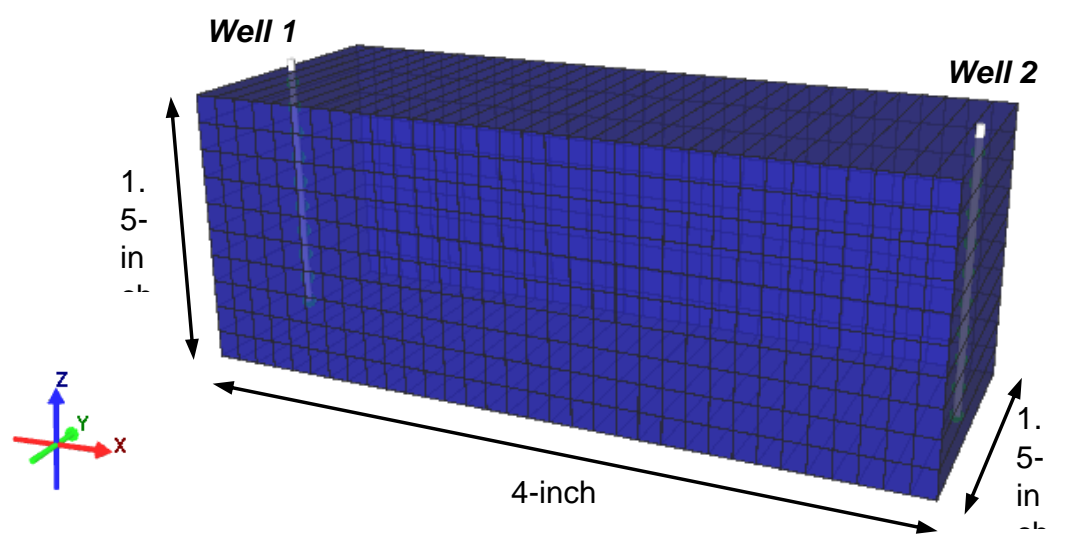

Figure 3. 3-D reservoir simulation model (blue area represents shale matrix)

\section{Results and Discussion}

The experimental RF results of tests \#1 to \#4 that obtained from core CEF_1 are shown in Table 5 and plotted in Figure 4. The flooding and huff-n-puff tests were performed under the same conditions of recovery time $(48 \mathrm{hr})$ and injection pressure $(1,000 \mathrm{psi})$. After a 2-day flooding process, $17.9 \%$ of oil in place was produced. The RF achieved by the huff-n-puff process was sensitive to the soaking time. Figure 4 shows that the case with 0.5 -hr soaking time yielded the most oil with $22.5 \%$ RF. Regarding the huff-n-puff process, within the same operation period, the test with a shorter soaking duration allows more cycles to be performed. With the increase in cycle number, it leads to the increase in cumulative RF. However, it does not imply that the shorter soaking time, the more oil could always be produced at the end. The reason is that if the soaking period is too short (such as a few minutes), only little oil could be extracted from a single cycle, which was observed from previous trial tests. Although an adequate number of cycles are available to be operated, the cumulative RF may be less than that from the case with a relative longer soaking time. A soaking period is necessary for the huff-npuff so that the pressure (or energy) can be transported to the inner area of the core and the gas can diffuse into the matrix. When the soaking time was 5 hours, the flooding mode outperformed the huff-n-puff mode in overall 2-day operation period. This indicates that optimization design of operating parameters in huff-n-puff is very important to achieve the maximum oil recovery, which also applies to maximize condensate recovery from gas condensate reservoirs (Meng and Sheng, 2016).

As the soaking time in a huff-n-puff process can affect its performance significantly, three huff-n-puff tests were operated under different soaking times. The figure 4 shows that the 
recovery performances between flooding and huff-n-puff with 2-hr soaking period were similar. It also presents that flooding had better performance than huff-n-puff with 5-hr soaking period (about $2.7 \%$ RF higher), and huff-n-puff with soaking 0.5 -hr had better performance than flooding (about $4.6 \%$ RF higher). It indicated that the optimization of huff-n-puff process (operating parameters design) is very important to maximize oil recovery.

Table 5. Recovery factor results from $\mathrm{N}_{2}$ flooding and $\mathrm{N}_{2}$ huff-n-puff tests in $48 \mathrm{hr}$

\begin{tabular}{ccccc}
\hline $\begin{array}{c}\text { Time } \\
\text { (hr) }\end{array}$ & $\begin{array}{c}\text { Test 1 } \\
\text { (flooding) }\end{array}$ & $\begin{array}{c}\text { Test 2 } \\
\text { (HNP, soaking 0.5-hr) }\end{array}$ & $\begin{array}{c}\text { Test 3 } \\
\text { (HNP, soaking 2-hr) }\end{array}$ & $\begin{array}{c}\text { Test 4 } \\
\text { (HNP, soaking 5-hr) }\end{array}$ \\
\hline 3 & - & $2.16 \%$ & $2.47 \%$ & - \\
6 & - & $6.30 \%$ & $5.01 \%$ & $3.29 \%$ \\
9 & - & $9.81 \%$ & $6.79 \%$ & - \\
12 & $6.85 \%$ & $12.92 \%$ & $8.06 \%$ & $5.45 \%$ \\
15 & - & $14.73 \%$ & $9.43 \%$ & - \\
18 & - & $16.42 \%$ & $10.71 \%$ & $7.42 \%$ \\
21 & - & $17.71 \%$ & $12.14 \%$ & - \\
24 & $12.31 \%$ & $18.72 \%$ & $13.21 \%$ & $9.19 \%$ \\
27 & - & $19.54 \%$ & $14.57 \%$ & - \\
30 & - & $20.51 \%$ & $15.29 \%$ & $11.05 \%$ \\
33 & - & $20.73 \%$ & $15.90 \%$ & - \\
36 & $15.69 \%$ & $21.46 \%$ & $16.46 \%$ & $12.55 \%$ \\
39 & - & $22.01 \%$ & $17.14 \%$ & - \\
42 & - & $22.32 \%$ & $17.73 \%$ & $13.88 \%$ \\
45 & - & $22.49 \%$ & $18.29 \%$ & - \\
48 & $17.94 \%$ & $22.52 \%$ & $18.86 \%$ & $15.28 \%$ \\
\hline
\end{tabular}




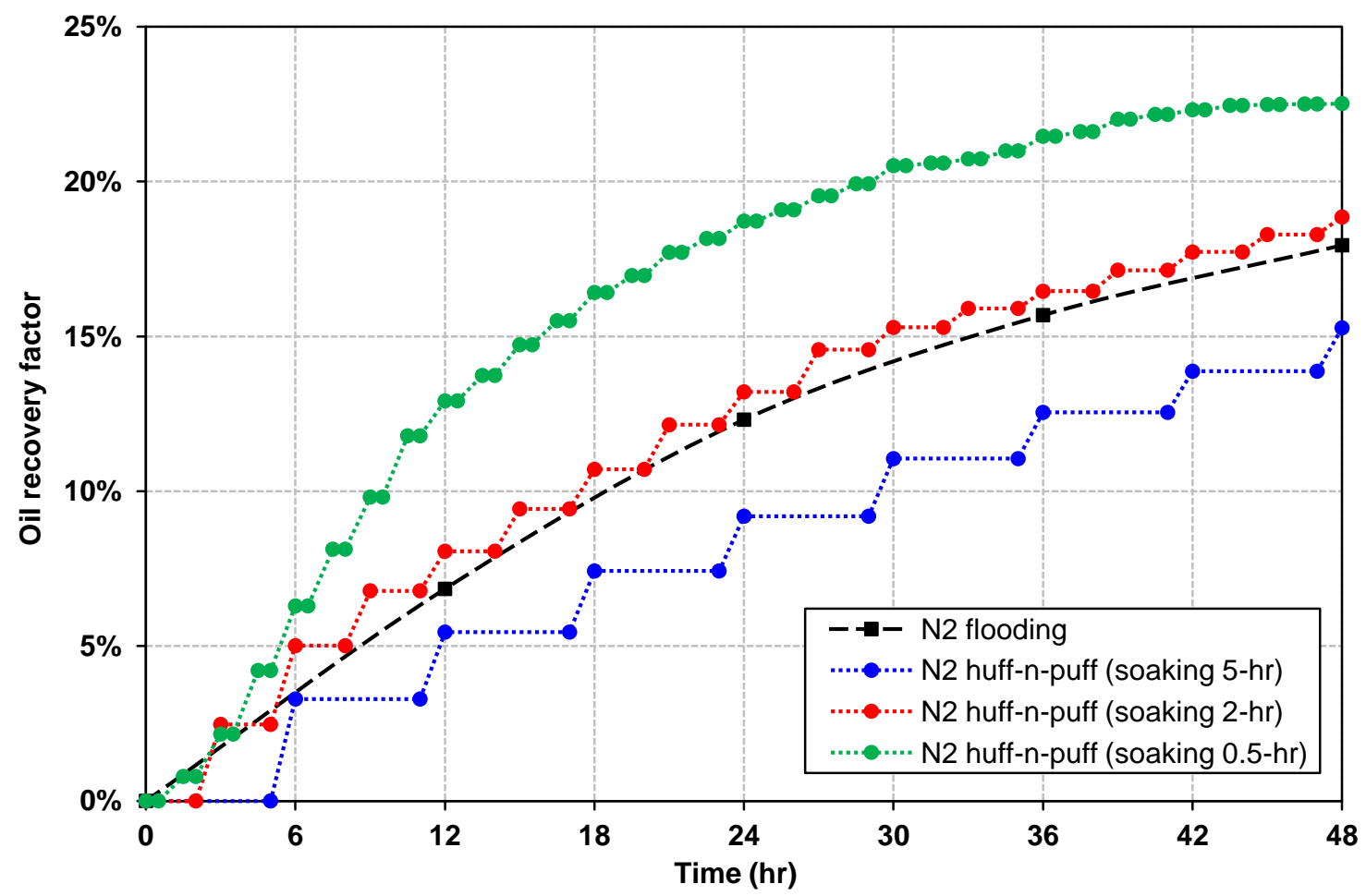

Figure 4 . Recovery histories by $\mathrm{N}_{2}$ flooding and $\mathrm{N}_{2}$ huff-n-puff in $48 \mathrm{hr}$

Figure 4 also illustrates that the huff-n-puff injection mode presents an effective and stable recovery potential at the early operation period. After performing a certain number of cycles, the incremental RF diminished with further cycles operated, thus extra more cycles will gradually make the huff-n-puff performance less efficient. Therefore, the ultimate recovery factor would be achieved after performing a certain number of cycles, and not much oil could be extracted after that.

Two series of $\mathrm{N}_{2}$ injection tests (\#5 and \#6) were performed on core CEF_2 for a 3-day oil recovery. The experimental results are presented in Table 6 . The RFs obtained from flooding and huff-n-puff (soaking $1 \mathrm{hr}$ and production $3 \mathrm{hr}$ ) were 19.9\% and $24.1 \%$, respectively. The base simulation model was tuned to match the experimental RF. Taking into account of the overall oil recovery trends of both injection modes, the simulation results by the two models showed good agreement with experimental data (see Figure 5). During the first $24 \mathrm{hr}$ operation period, two injection modes presented similar recovery histories and yielded similar amount of oil. After that, the difference of cumulative RF between flooding and huff-n-puff started to show up and expanded with the recovery time. The production rate in the flooding case decreased substantially because the gas had broken through in $24 \mathrm{hr}$. The majority of injected gas passed through the established flow channel, thus the flooding's recovery performance became less effective. By comparison, the huff-n-puff process offered consistent injection energy during each cycle, which recharged the matrix cyclically and maintain a relatively longer effective recovery performance. Extending the operation period to 15 days, we predicted the trends in oil production of both modes (Figure 6). It shows that the difference in RFs from huff-n-puff and flooding increased from the second day and became stabilized after 6 days' operation as the 
recovery profiles developed in parallel. The cumulative RF obtained by the huff-n-puff process was approximately higher $11 \%$ than that from the flooding process.

In our previous study, the core plugs with different diameters and lengths were used in the gas huff-n-puff tests. The results show that using the identical operation schedules, a core with a larger diameter will have a lower oil recovery in the same injection cycle and lower cumulative oil recovery after all the huff-n-puff cycles (Li and Sheng, 2016). The sensitivity analysis of the numerical model illustrates that the most important parameter during gas huff-n-puff EOR process is injection pressure, followed by matrix permeability, porosity, and methane diffusivity. When upscaling the core size to the field level, the oil recovery decreased (Li et al., 2016). The field simulation results conducted by Wan and Sheng (2015b) indicate that total oil recovery can be increased up to $29 \%$ by cyclic gas injection, compared with the $6.5 \%$ recovery from the primary depletion. The two methods, gas flooding and gas huff-n-puff, are also implemented in the experiments of gas condensate study by Meng et al. (2016). Their results indicate that the efficiency of huff-n-puff ( $25 \% \mathrm{RF})$ was higher than that of gas flooding (19\% RF). Similar results are seen in Sheng and Ke (2014). Thus all the study indicates that huff-n-puff has better performance than gas flooding on enhancing oil recovery in shale reservoirs. This conclusion is also verified for huff-n-puff gas injection in gas condensate reservoirs (Sheng et al., 2016).

Table 6. Recovery factor results from $\mathrm{N}_{2}$ flooding and $\mathrm{N}_{2}$ huff-n-puff tests in $72 \mathrm{hr}$

\begin{tabular}{ccc|ccc}
\hline $\begin{array}{c}\text { Time } \\
(\mathrm{hr})\end{array}$ & $\begin{array}{c}\text { Test 5 } \\
(\text { HNP, soaking 1 hr) }\end{array}$ & $\begin{array}{c}\text { Test 6 } \\
\text { (flooding) }\end{array}$ & $\begin{array}{c}\text { Time } \\
(\mathrm{hr})\end{array}$ & $\begin{array}{c}\text { Test 5 } \\
\text { (HNP, soaking 1 hr) }\end{array}$ & $\begin{array}{c}\text { Test 6 } \\
\text { (flooding) }\end{array}$ \\
\hline 4 & $1.78 \%$ & - & 40 & $18.12 \%$ & - \\
8 & $3.59 \%$ & - & 44 & $19.11 \%$ & - \\
12 & $5.92 \%$ & - & 48 & $19.83 \%$ & $16.67 \%$ \\
16 & $9.32 \%$ & - & 52 & $20.97 \%$ & - \\
20 & $11.25 \%$ & - & 56 & $21.86 \%$ & - \\
24 & $12.98 \%$ & $11.57 \%$ & 60 & $22.49 \%$ & - \\
28 & $14.73 \%$ & - & 64 & $23.21 \%$ & - \\
32 & $16.03 \%$ & - & 68 & $23.57 \%$ & - \\
36 & $17.10 \%$ & - & 72 & $24.13 \%$ & $19.88 \%$ \\
\hline
\end{tabular}




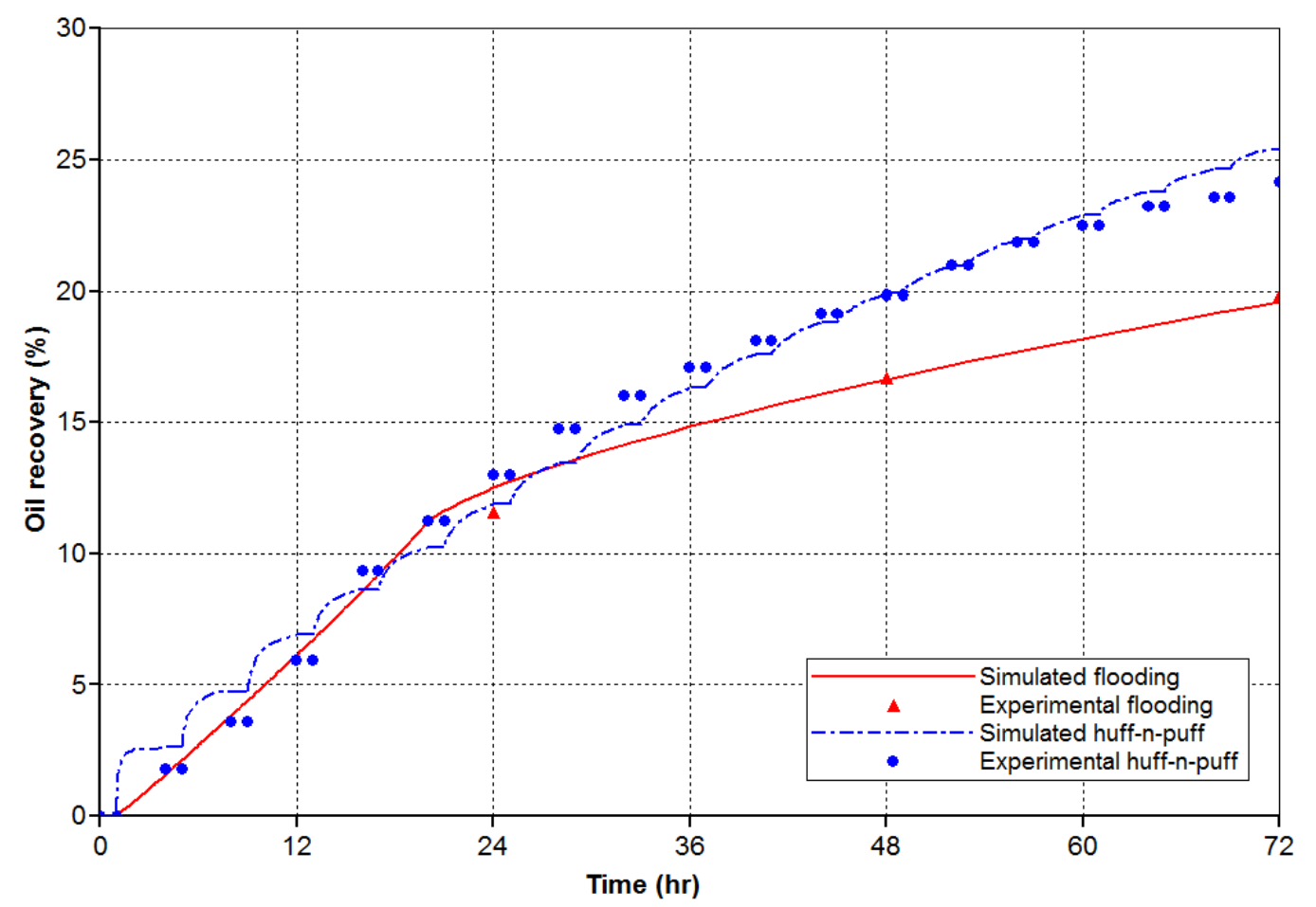

Figure 5. Experimental and simulated oil recovery histories by $\mathrm{N}_{2}$ flooding and $\mathrm{N}_{2}$ huff-n-puff in $72 \mathrm{hr}$

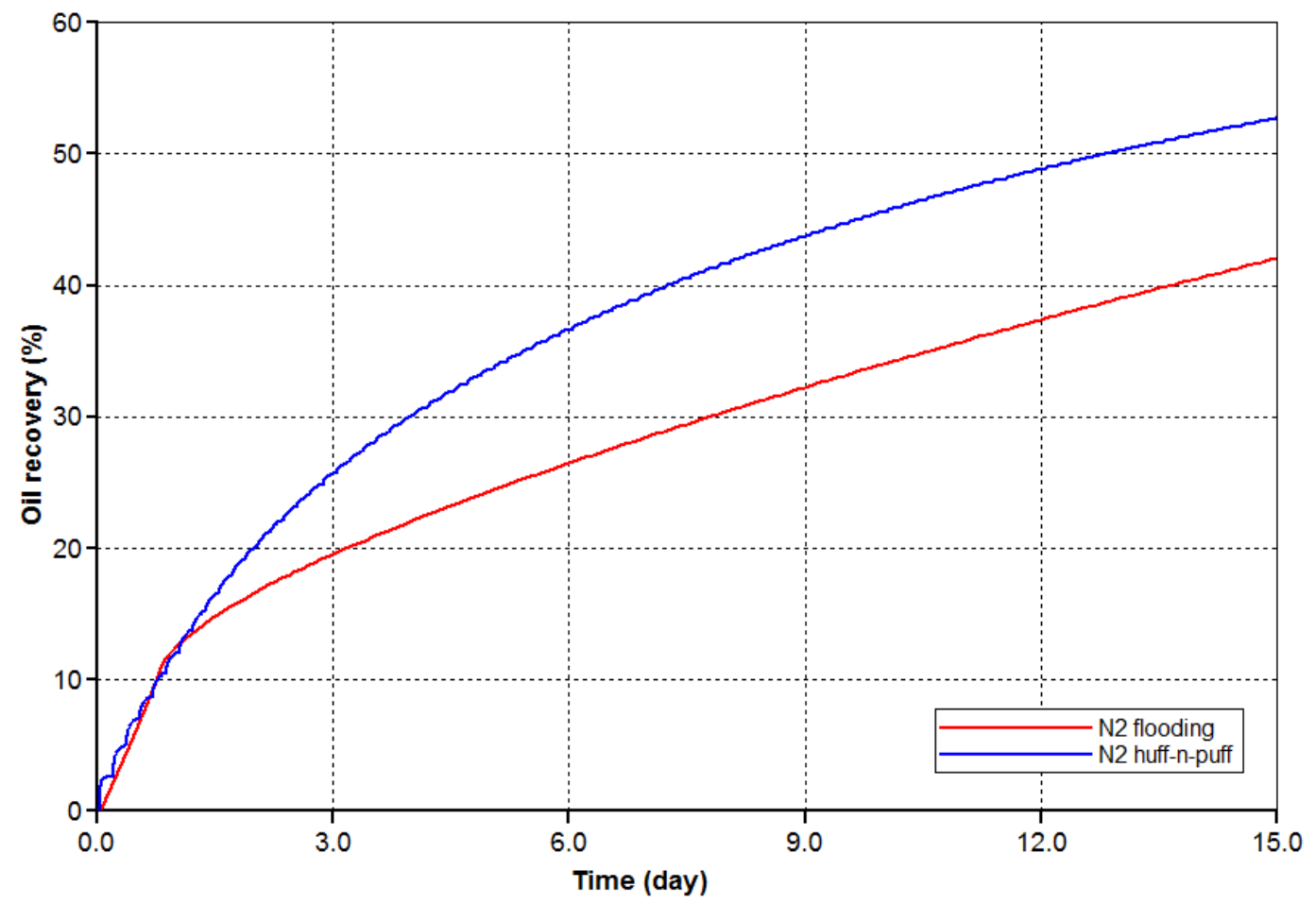

Figure 6. Prediction of oil recovery trends by $\mathrm{N}_{2}$ flooding and $\mathrm{N}_{2}$ huff-n-puff 


\section{Conclusions}

This study examined and compared the recovery efficiencies of $\mathrm{N}_{2}$ flooding and $\mathrm{N}_{2}$ huff-npuff in shale plugs by experimental work. Lab-scale simulation models were built to simulate both recovery processes. The conclusions drawn from this investigation are as follows.

- The experimental results show that the gas injection mode of huff-n-puff is superior to the flooding mode in shale core plugs, with a higher cumulative oil recovery during the same operation period.

- Gas flooding showed similar recovery efficiency as huff-n-puff before breakthrough. After that, the production rate by flooding declined with the operation period, and huff-n-puff began to show more oil produced.

- Compared with gas flooding, gas huff-n-puff process presented more durable and steadier IOR performance.

- For the huff-n-puff process, optimization design of key operating parameters, such as soaking time and cycle number, is crucial to achieve the maximum production, compared with the flooding process.

- Based on the core-scale simulation study, the $\mathrm{N}_{2}$ huff-n-puff could contribute more RF than the $\mathrm{N}_{2}$ flooding (e.g. $11 \%$ for the cases studied).

\section{Acknowledgement}

This work was supported by the U.S. Department of Energy under Award Number DEFE0024311.

\section{References}

CMG. 2014. CMG Manual. GEM, Compositional \& Unconverional Reservoir Simulator Version.

Dong, C. and Hoffman, B.T. 2013. Modeling Gas Injection into Shale Oil Reservoirs in the Sanish Field, North Dakota. Presented at the SPE Unconventional Resources Technology Conference, Denver, Colorado, USA, 12-14 August. SPEhttp://dx.doi.org/10.1190/URTEC2013-185.

Energy Information Administration (EIA). 2016a. "World tight oil production to more than double from 2015 to 2040." Today in Energy, 12 August 2016. https://www.eia.gov/todayinenergy/detail.cfm?id=27492 (accessed 12 August 2016).

Energy Information Administration (EIA). 2016b. "EIA projects rise in U.S. crude oil and other liquid fuels production beyond 2017." Today in Energy, 11 July 2016. https://www.eia.gov/todayinenergy/detail.cfm?id=27012 (accessed 2 August 2016).

Gamadi, T.D., Sheng, J.J., and Soliman, M.Y. 2013. An Experimental Study of Cyclic Gas Injection to Improve Shale Oil Recovery. Presented at the SPE Annual Technical Conference and Exhibition, New Orleans, Louisiana, USA, 30 September-2 October. SPE-166334-MS. http://dx.doi.org/10.2118/166334-MS.

Gamadi, T.D., Sheng, J.J., Soliman, M.Y. et al. 2014. An Experimental Study of $\mathrm{Cyclic}^{\mathrm{CO}_{2}}$ Injection to Improve Shale Oil Recovery. Presented at the SPE Improved Oil Recovery Symposium, Tulsa, Oklahoma, USA, 12-16 April. SPE-169142-MS. http://dx.doi.org/10.2118/169142-MS. 
Hoffman, B.T. and Evans, J.G. 2016. Improved Oil Recovery IOR Pilot Projects in the Bakken Formation. Presented at the SPE Low Perm Symposium, Denver, Colorado, USA, 5-6 May. SPE-180270-MS. http://dx.doi.org/10.2118/180270-MS.

Kong, B., Wang, S., and Chen, S. 2016. Simulation and Optimization of $\mathrm{CO}_{2}$ Huff-and-Puff Processes in Tight Oil Reservoirs. Presented at the SPE Improved Oil Recovery Conference, Tulsa, Oklahoma, USA, 11-13 April. SPE-179668-MS. http://dx.doi.org/10.2118/179668-MS.

Li, L., Sheng, J. J. 2016. Experimental Study of Core Size Effect on $\mathrm{CH}_{4}$ Huff-N-Puff Enhanced Oil Recovery in Liquid-rich Shale Reservoirs. Journal of Natural Gas Science and Engineering 34: 1392-1402. http://dx.doi.org/10.1016/j.jngse.2016.08.028.

Li, L., Sheng, J.J., Watson, M., Mody, F. 2015. Experimental and Numerical Upscale Study of Cyclic Methane Injection to Enhance Shale Oil Recovery. Paper 425710 presented at the AIChE Annual Meeting, Salt Lake City, Utah, 8-13 November.

Li, L., Sheng, J.J., and Sheng, J. 2016. Optimization of Huff-n-Puff Gas Injection to Enhance Oil Recovery in Shale Reservoirs. Presented at the SPE Low Perm Symposium, Denver, Colorado, USA, 5-6 May. http://dx.doi.org/10.2118/180219-MS

Ma, Y.Z. 2015. Unconventional Resources from Exploration to Production. Unconventional Oil and Gas Resources Handbook: Evaluation and Development (2015). Elsevier.

Meng, X. and Sheng, J.J. 2016. Optimization of huff-n-puff gas injection in a shale gas condensate reservoir, Journal of Unconventional Oil and Gas Resources, 16, 34-44.

Meng, X., Sheng, J. J., and Yu, Y. 2016. Experimental and Numerical Study of Enhanced Condensate Recovery by Gas Injection in Shale Gas-Condensate Reservoirs. SPE Reservoir Evaluation \& Engineering, preprint online.

Sheng, J.J. 2015. Enhanced Oil Recovery In Shale Reservoirs By Gas Injection. Journal of Natural Gas Science and Engineering 22, 252-259. http://dx.doi.org/10.1016/j.jngse.2014.12.002.

Sheng, J.J. and Chen, K. 2014. Evaluation of the EOR Potential of Gas and Water Injection in Shale Oil Reservoirs, Journal of Unconventional Oil and Gas Resources, 5, 1-9.

Sheng, J.J., Mody, F., Griffith, P.J., and Barnes, W.N. 2016. Potential to increase condensate oil production by huff-n-puff gas injection in a shale condensate reservoir, J. of Natural Gas Science and Engineering, 28, 46-51.

Song, C. and Yang, D. 2013. Performance Evaluation of CO2 Huff-n-Puff Processes in Tight Oil Formations. Presented at the SPE Unconventional Resources Conference Canada, Calgary, Alberta, Canada, 5-7 November. SPE-167217-MS. http://dx.doi.org/10.2118/167217-MS.

Wan, T. and Sheng, J.J. 2015a. Enhanced Recovery of Crude Oil From Shale Formations by Gas Injection in Zipper-fractured Horizontal Wells. Petroleum Science and Technology 33 (17-18): 1605-1610. http://dx.doi.org/10.1080/10916466.2015.1079536.

Wan, T., Sheng, J. J., 2015b. Evaluation of the EOR Potential in Hydraulically Fractured Shale Oil Reservoirs by Cyclic Gas Injection. Petroleum Science and Technology 33 (7): 812818. http://dx.doi.org/10.1080/10916466.2015.1010041.

Wan, T., Yu, Y., and Sheng, J.J. 2014. Comparative Study of Enhanced Oil Recovery Efficiency by $\mathrm{CO}_{2}$ Injection and $\mathrm{CO}_{2}$ Huff-N-Puff in Stimulated Shale Oil Reservoirs. Paper 353987 presented at the AIChE Annual Meeting, Atlanta, Georgia, 16-21 November.

Yu, Y. 2016. Experimental Study of Enhanced Liquid Oil Recovery from Shale Reservoirs by Gas Injection, Texas Tech University, Lubbock, Texas, May. 
Yu, W., Al-Shalabi, E.W., and Sepehrnoori, K. 2014. A Sensitivity Study of Potential $\mathrm{CO}_{2}$ Injection for Enhanced Gas Recovery in Barnett Shale Reservoirs. Present at the SPE Unconventional Resources Technology Conference, The Woodlands, Texas, USA, 1-3 April. SPE-169012-MS. http://dx.doi.org/10.2118/169012-MS.

Yu, Y., Li, L., and Sheng, J.J. 2016a. Further Discuss the Roles of Soaking Time and Pressure Depletion Rate in Gas Huff-n-Puff Process in Fractured Liquid-rich Shale Reservoirs. Prepared for the SPE Annual Technical Conference and Exhibition, Dubai, UAE, 26-28 September. SPE-181471-MS.

Yu, Y., Meng, X., and Sheng, J.J. 2016b. Experimental and Numerical Evaluation of the Potential of Improving Oil Recovery from Shale Plugs by Nitrogen Gas Flooding. Journal of Unconventional Oil and Gas Resources 15: 56-65. http://dx.doi.org/10.1016/j.juogr.2016.05.003.

Yuan, B., D. A., Wood. 2015. Production Analysis and Performance Forecasting for Natural Gas Reservoirs: Theory and Practice (2011-2015). Journal of Natural Gas Science and Engineering 26: 1433-1438. http://dx.doi.org/10.1016/j.jngse.2015.08.024.

Yuan, B., Moghanloo, R. G., and Shariff, E. 2016. Integrated Investigation of Dynamic Drainage Volume and Inflow Performance Relationship (Transient IPR) to Optimize Multistage Fractured Horizontal Wells in Tight/Shale Formations. Journal of Energy Resources Technology 138(5): 052901. http://dx.doi.org/10.1115/1.4032237.

Zhu, P., Balhoff, M.T., and Mohanty, K.K. 2015. Simulation of Fracture-to-Fracture Gas Injection in an Oil-Rich Shale. Presented at the SPE Annual Technical Conference and Exhibition, Houston, Texas, USA, 28-30 September. SPE-175131-MS. http://dx.doi.org/10.2118/175131-MS. 